\begin{tabular}{cc}
\hline UNIVERSITAS AHMAD DAHLAN \\
JURNAL BIOEDUKATIKA \\
23 http://journal.uad.ac.id/index.php/BIOEDUKATIKA \\
$2338-6630$ (Print)
\end{tabular}

\title{
Analisis kualitas butir soal instrumen Assessment Diagnostic untuk mendeteksi miskonsepsi siswa SMA pada materi virus
}

\author{
Prima Mitha Puspitasari Setyaningrum a, 1, Murni Ramli b, 2*, Yudi Rinanto ${ }^{b, 3}$ \\ ${ }^{a}$ Magister Pendidikan Sains, Pascasarjana, Universitas Sebelas Maret, J1. Ir. Sutami 36A, Surakarta 57126, Indonesia \\ ${ }^{\mathrm{b}}$ Pendidikan Biologi, Fakultas Keguruan dan Ilmu Pendidikan Biologi, Universitas Sebelas Maret J1 Ir. Sutami 36A, Surakarta 57126, \\ Indonesia \\ ${ }^{1}$ pprimamitha@yahoo.com; ${ }^{2}$ mramlim04@fkip.uns.ac.id; ${ }^{3}$ yudi.rinanto@gmail.com \\ *korespondensi penulis
}

\begin{tabular}{ll}
\hline Informasi artikel & \\
\hline Sejarah artikel: & \\
Diterima & 18 Agustus 2018 \\
Revisi & 19 November 2018 \\
Dipublikasikan & 22 Desember 2018 \\
\hline
\end{tabular}

Kata kunci:

Analisis butir soal

Assessment Diagnostic

Kolom Bukti Fakta

Structure Communication Grid

\section{ABSTRAK}

Evaluasi merupakan kegiatan, untuk melihat sejauh mana keberhasilan pembelajaran telah dilaksanakan. Kegiatan evaluasi memerlukan alat sebagai pengumpul data yang disebut instrumen. Sebuah instrumen dikatakan baik apabila memenuhi beberapa kriteria. Salah satunya dengan melakukan analisis butir soal. Penelitian ini bertujuan untuk mengetahui validitas, reliabilitas, tingkat kesukaran, dan daya pembeda soal pada insrumen diagnostic materi virus. Responden penelitian berjumlah 346 siswa kelas X, XI, dan XII SMA Negeri dan Swasta di Kota Magelang. Instrumen yang diberikan berupa Assessment Diagnostic pada materi virus, yang terdiri dari soal Kolom Bukti Fakta (KBF), essay, dan Structure Communication Grid (SCG). Penelitian ini merupakan penelitian kuantitatif untuk mengetahui kualitas instrumen. Hasil penelitian menunjukkan persentase validitas soal KBF dan SCG 63,2\%, soal essay $100 \%$, semua soal reliabel, tingkat kesukaran soal mudah KBF dan SCG $38,6 \%$, soal sedang $37,1 \%$, dan $24,3 \%$ soal sukar. Sedangkan kesukaran soal essay $20 \%$ pada kategori mudah dan $80 \%$ pada kategori sedang. Daya pembeda soal $\mathrm{KBF}$ dan SCG sebesar 62,2\% kategori jelek, 31,5\% kategori cukup, 6,3\% kategori baik. Daya pembeda soal essay $60 \%$ soal pada kategori cukup dan $40 \%$ soal kategori baik. Berdasarkan hasil analisis, dilakukan perbaikan butir soal. Instrumen pada materi virus yang sedang dikembangkan, merupakan yang pertama di Indonesia.

Key word:

Analysis of items

Assessment Diagnostic

Column Evidence of Facts

Structure Communication Grid

\section{ABSTRACT}

Quality analysis of item in the Assessment Diagnostic instrumen to detect misconceptions in high school students on virus material. Evaluation is an activity to see the extent to which the success of learning has been carried out. Evaluation activities require tools as data collectors called instrumens. An instrumenis good, if it meets several criteria. One of them is by analyzing questions' item. This study was aimed to determine the validity, reliability, level of difficulty, and differentiation of problems in the diagnostic instrumens of virus material. Respondents in this study are 346 students of class X, XI, XII of public and private High Schools in Magelang City. The instrumen provided is in the form of a Diagnostic Assessmenton virus material, which consists of the Facts Proof Column (KBF), essay and Structure Communication Grid (SCG). This research is a quantitative studywhich determine the quality of the instrumen. The results showed the percentageof the validity of $\mathrm{KBF}$ and SCG questions was $63,2 \%$, essay questionswere $100 \%$, all questions are reliable, the level of difficulty of easy questions of KBF and SCG is 38,6\%, moderate questions are $37,1 \%$, and $24,3 \%$ are difficult questions. While the difficulty of the essay is $20 \%$ in the easy category and $80 \%$ in the medium category. The differentiation of the KBF and SCG questions is $62,2 \%$ in the bad category, $31,5 \%$ in the sufficient category, $6,3 \%$ in the good category. The differentiation of essay questions $60 \%$ in adequate category and $40 \%$ in good categories. Based on the analysis, further improvements were made to the items. Instrumens in the virus material which are being developed are the first in Indonesia. 


\section{Pendahuluan}

Proses pembelajaran merupakan sistem yang meliputi tiga komponen pokok, yaitu merancang, melaksanakan, dan melakukan evaluasi kegiatan pembelajaran. Ketiga komponen tersebut saling berkaitan dan berinteraksi dalam mencapai tujuan pembelajaran. Melalui kegiatan evaluasi, kemajuan program pembelajaran yang telah dilaksanakan dapat diketahui (Borualogo, Kusdiyati, Susandari, \& Sirodj, 2017). Proses evaluasi tidak hanya mengukur sejauh mana tujuan tercapai, namun menentukan keputusan lanjutan dalam kegiatan pembelajaran.

Evaluasi sebagai kegiatan terstruktur, menyeluruh, dan berkelanjutan dalam upaya penjaminan dan pengendalian mutu pembelajaran. Sehubungan dengan evaluasi pembelajaran, maka sangat penting untuk dilakukan penilaian pembelajaran. Clark (2015) telah berhasil melakukan identifikasi tiga tujuan penilaian yang berbeda, namun berkaitan satu sama lain, yaitu penilaian pembelajaran (Assessment of Learning), penilaian sebagai pembelajaran (Assessment as Learning), dan penilaian untuk pembelajaran (Assessment for Learning). Assessment Diagnostic yang dikembangkan dalam penelitian ini merupakan bagian dari $A f L$, yang merupakan penilaian formatif dan bertujuan untuk memperbaiki pembelajaran berikutnya. Penyusunan Assessment Diagnostic dikhususkan pada materi virus, yang belum pernah dikembangkan di Indonesia.

Evaluasi berkaitan erat dengan kegiatan pengumpulan data, dimana diperlukan alat yang disebut instrumen. Pengumpulan data dalam kegiatan evaluasi pendidikan, berupa tes atau non tes (Purwanto, 2011). Teknik tes digunakan untuk mengetahui hasil belajar kognitif, sedangkan teknik non tes untuk mengukur hasil belajar afektif (aspek sikap) dan psikomotorik (aspek keterampilan). Penggunaan alat sebagai teknik penilaian, bertujuan agar pelaksanaan pembelajaran menjadi terarah.

Hasil wawancara terhadap guru biologi dan siswa SMA di Kota Magelang pada November 2017, diketahui bahwa instrumen penilaian yang digunakan seringkali diperoleh dari buku paket atau soal kumpulan ujian. Bentuk soal yang diujikan kepada siswa yaitu multiple choice (pilihan ganda) dan essay (uraian). Soal berbentuk pilihan ganda dan essay hanya menguji aspek ingatan yang akan membuat siswa untuk belajar dengan cara menghafal materi bukan memahami materi. Soal-soal yang menguji aspek ingatan termasuk dalam ranah kognitif level bawah yaitu C1 (hafalan/ingatan) dan C2 (pemahaman). Akibatnya siswa tidak terbiasa untuk berpikir tingkat tinggi, yang berdampak pada ketidakmampuan siswa dalam menghubungkan pengetahuan yang dimilikinya ketika dihadapkan pada soal yang menuntut analisis maupun evaluasi dalam pembelajaran.

Biologi mempelajari kehidupan organisme, lingkungan, dan relasi tentang keduanya. Materi biologi terdiri atas objek yang bersifat konkret dan objek yang bersifat abstrak. Objek konkret teramati melalui fenomena alam yang terjadi. Sedangkan objek yang bersifat abstrak diantaranya: proses metabolisme di dalam tubuh manusia (meliputi: sistem saraf, sistem indra, sistem hormon, sistem koordinasi, dan sebagainya). Sifat objek pada materi biologi sangat beragam, baik ditinjau dari ukuran organisme (makroskopis seperti: animalia dan plantae; mikroskopis seperti: virus, bakteri, protista), keterjangkauan (ekosistem dan komponen penyusun didalamnya), sifat pathologi/penyebab penyakit (virus, bakteri, protista, organisme lain), dan sebagainya (Sudarisman, 2015). Sejalan dengan hal tersebut, Jayawardana (2017) berpendapat bahwa "Proses belajar mengajar pada pembelajaran biologi seringkali dihadapkan pada materi abstrak dan di luar pengalaman siswa sehari-hari, sehingga materi menjadi sulit dipahami siswa”. Beberapa materi biologi melibatkan proses-proses yang saling berhubungan, yaitu: sistem digesti (gerakan peristaltik kerongkongan hingga lambung), respirasi (proses inspirasi dan ekspirasi pernapasan dada serta perut), genital (proses fertilisasi hingga terbentuknya zigot), cardiovascular (hubungan antara kerja jantung dan pembuluh darah), dan sebagainya (Jayawardana, 2017).

Ayu, Saputri, \& Widyaningrum (2016), menyatakan bahwa "Materi virus merupakan salah satu materi yang sulit untuk dibelajarkan dan sulit untuk dipahamkan kepada siswa”. Konsep virus yang diajarkan pada tingkat SMA meliputi: ciri-ciri virus sebagai peralihan benda mati dan makhluk hidup, struktur tubuh virus yang membedakannya dengan benda mati maupun organisme aseluler, dasar klasifikasi virus, replikasi virus dalam menginfeksi inangnya, dan peranan virus. Partikel virus berukuran mikroskopis dan sangat sederhana jika dibandingkan bakteri maupun prokariota, virus tidak memiliki komponen penyusun sel, serta tidak bermetabolisme di luar sel inang. Karakteristik partikel virus yang tidak dapat dilihat oleh mata tanpa alat khusus, berakibat pada terbentuknya pemikiran abstrak siswa yang berkembang menjadi miskonsepsi (Güne, Güne, \& Hoplan, 2011).

Miskonsepsi adalah konsepsi atau pandangan tentang sains yang berbeda dengan konsep yang sebelumnya telah disepakati oleh para ahli (Kose, Pekel, \& Hasenekoglu, 2009). Suratno (2008), menyatakan bahwa sebelum mengikuti pembelajaran 
sebenarnya siswa sudah memiliki pemikiran sendiri terhadap suatu konsep, dan mereka akan membawa konsepsi tersebut ke dalam kelas. Apabila konsepsi tersebut salah, maka akan menjadi miskonsepsi yang jika tidak diperbaiki akan terus menjadi kesalahan konsep pada siswa (Gurel, Ery1lmaz, \& McDermott, 2015). Miskonsepsi mudah muncul dalam konteks menjelaskan fenomena yang ditemui sehari-hari di lingkungan sekitar (Chi, Slotta, \& Leeuw, 1994). Sejalan dengan hal tersebut, Aprilia (2016) berpendapat "Pemahaman konsep sebenarnya merupakan jenjang kemampuan berpikir yang setingkat lebih tinggi dari ingatan dan hafalan”.

Kara \& Çelikler (2015) menyatakan "Dalam pembelajaran, guru memiliki peran sentral dalam upaya merubah kesalahan konseptual (miskonsepsi) siswa yaitu dengan mengembangkan dan mengevaluasi pembelajaran yang terjadi dalam kelas". Miskonsepsi dapat dideteksi dengan menemukan penyebab miskonsepsi tersebut melalui teknik tes. Beberapa bentuk tes yang dapat digunakan untuk mendeteksi miskonsepsi yaitu: metode diskusi, praktikum tanya jawab, Certainty of Response Index (CRI), tes pilihan ganda disertai alasan terbuka, peta konsep, tes essay tertulis, wawancara, dan tes diagnostik (Suparno, 2013).

Terdapat beberapa instrumen diagnostik yang telah dikembangkan pada penelitian-penelitian sebelumnya untuk melacak terjadinya miskonsepsi, yaitu: 1) Tes certainty of response index (CRI). Metode CRI dapat mengeksplorasi pemahaman sains, tingkat kepercayaan diri, dan mengidentifikasi miskonsepsi yang terjadi (Mustaqim, Zulfiani, \& Herlanti, 2014), 2) Instrumen two-tier multiple choice question yang dikembangkan pada materi Plantae dapat melatihkan kemampuan berpikir tingkat tinggi (HOTs) (Nofiana, Sajidan, \& Puguh, 2016), 3) Instrumen three-tier diagnostic test, yaitu tes dengan tiga tingkatan soal (Syahrul \& Setyarsih, 2015). Penelitian pada materi virus yang telah dilakukan Ayu et al. (2016) menyatakan bahwa terdapat miskonsepsi pada buku teks, yang berimbas pada kesalahan siswa dalam memahami konsep pada materi virus. Belum adanya tes diagnostik, terutama dalam bentuk KBF dan SCG menjadi dasar bagi peneliti untuk menyusun suatu instrumen penilaian berupa Assessment Diagnostic pada materi virus.

Tes diagnostik merupakan suatu jenis $A f L$ atau penilaian untuk pembelajaran yang dapat memberikan umpan balik kepada guru maupun siswa terkait kemajuan pembelajaran dalam mencapai tujuan pembelajaran (Yankovskaya, Levin, \& Fuks, 2014). Umpan balik ini akan dipergunakan oleh guru untuk merevisi dan mengembangkan pengajaran berikutnya.
Tes diagnostik yang disusun berupa Kolom Bukti Fakta (KBF), merupakan tes yang diadopsi dari "Resources Pack" King College London yang dikembangkan oleh Osborne (2004), sedangkan Structure Communication Grid (SCG) diadopsi dari penelitian Johnstone, Bahar, \& Hansell (2000). Tes diagnostik $\mathrm{KBF}$ mampu mengukur tingkat pemahaman konsep siswa terhadap key concept pada pokok bahasan tertentu, yang cenderung dipahami secara salah. Tes SCG digunakan untuk mengetahui tingkat pemahaman siswa tentang konsep yang berupa suatu tahapan atau siklus.

Penggunaan tes diagnostik KBF dan SCG memberikan gambaran kepada guru tentang konsepkonsep yang sulit dipahami oleh siswa, serta mengetahui kelemahan siswa tentang materi yang diajarkan. Hal ini sejalan dengan pemikiran Yankovskaya et al., (2014), "Kelemahan siswa dapat dideteksi dengan menggunakan tes diagnostik".

Tes diagnostik KBF dan SCG yang dikembangkan pada penelitian ini adalah instrumen untuk mendeteksi miskonsepsi pada materi virus. Tes diagnostik yang dikembangkan perlu diuji coba untuk mengetahui tingkat keefektifan dalam melacak siswa yang kemungkinan mengalami paham konsep, miskonsepsi, dan tidak paham konsep. Selanjutnya dari hasil jawaban siswa, dilakukan analisis kuantitatif butir soal untuk mengetahui seberapa baik instrumen tersebut dapat mengukur miskonsepsi siswa. Assessment Diagnostic materi virus yang dikembangkan, diharapkan dapat memberikan gambaran kepada guru mengenai jenis penilaian guna memperbaiki proses pembelajaran di sekolah.

Penelitian mengenai kesulitan pembelajaran pada materi virus sebelumnya telah dilakukan oleh beberapa peneliti. Akan tetapi belum ada penelitian yang mengkaji lebih dalam tentang penggunaan Assessment for Learning yang mampu mendeteksi miskonsepsi siswa. Beberapa pertimbangan tersebut, melatarbelakangi peneliti untuk menyusun butir soal instrumen Assessment Diagnostic pada materi virus, Penelitian ini bertujuan untuk mengetahui kualitas butir soal instrumen. Selanjutnya hasil analisis butir soal digunakan sebagai salah satu dasar perbaikan instrumen soal sebelum dilakukan uji coba kedua.

\section{Metode}

Penelitian ini merupakan penelitian deskriptif kuantitatif untuk mengecek kualitas instrumen. Data yang diperoleh berasal dari jawaban siswa, dianalisis menggunakan aplikasi IBM SPSS Statistics versi 21. Tahapan penelitian yang dilakukan, yaitu: 1) Menyusun instrumen soal berupa KBF disertai essay, dan SCG untuk mendeteksi miskonsepsi siswa pada 
materi virus, 2) Melakukan validasi terkait content materi bersama validator ahli, 3) Melakukan survey di SMA di Kota Magelang yang akan dijadikan tempat penelitian, 4) Menentukan jumlah responden yang terlibat berdasarkan penentuan populasi siswa, 5) Melaksanakan pengujian instrumen kepada 346 siswa sebagai responden, 6) Menganalisis hasil uji coba soal menggunakan aplikasi IBM SPSS Statistic versi 21.

Sekolah yang menjadi sampel dalam penelitian ditentukan berdasarkan teknik cluster sampling. Dari 12 SMA di Kota Magelang, sebanyak 6 sekolah dipilih berdasarkan kriteria jenis sekolah, yaitu sekolah negeri dan swasta. Jumlah responden pada setiap SMA yang terlibat ditentukan berdasarkan teknik proportionate stratified random sampling, yaitu sekitar 20 siswa dari setiap kelas untuk setiap grade X, XI, dan XII SMA yang telah memperoleh materi virus di sekolah. Siswa di SMA negeri dan swasta di Kota Magelang berjumlah 5045 siswa, sedangkan siswa dari 6 sekolah yang dipilih sebagai responden penelitian berjumlah 3046 siswa. Dari total siswa 6 SMA tersebut, yang terlibat dalam tes miskonsepsi sebanyak 346 siswa.

Jumlah sampel ditentukan berdasarkan formula Isaac \& Michael, (1995), dengan rumus:

$$
\mathrm{S}=\frac{\mathrm{X}^{2} \cdot \mathrm{N} \cdot \mathrm{P}(1-\mathrm{P})}{\mathrm{d} 2(\mathrm{~N}-1)+\mathrm{X} 2 \mathrm{P}(1-\mathrm{P})}
$$

Keterangan: $\mathrm{S}=$ jumlah sampel, $\mathrm{N}=$ jumlah populasi, $\mathrm{P}=$ proporsi populasi sebagai dasar asumsi pembuatan tabel (ditetapkan $\mathrm{P}=0.5$ ), $\mathrm{d}=$ derajat ketetapan yang direfleksikan oleh kesalahan yang dapat ditoleransi dalam fluktuasi proporsi sampel P (umumnya ditetapkan $0.5), \mathrm{X}^{2}=$ Nilai tabel chi square untuk satu derajat kebebasan relatif level konfiden yang diinginkan $\left(\mathrm{X}^{2}=3.841\right.$ tingkat kepercayaan 0.95$)$.

\begin{tabular}{|c|c|c|c|c|}
\hline \multirow[t]{3}{*}{$\begin{array}{l}\text { a) } \\
\text { b) }\end{array}$} & \multicolumn{4}{|c|}{ 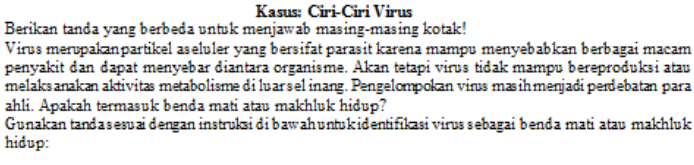 } \\
\hline & \multirow{2}{*}{\multicolumn{4}{|c|}{$\begin{array}{l}\text { Bukti yang mengatakan virus ad alah malfilukhidup } \\
\text { Bukti yang mengatakan virus ad alahbenda mati }\end{array}$}} \\
\hline & & & & \\
\hline \multicolumn{5}{|c|}{ Lembar soal: } \\
\hline 1. & & $\begin{array}{l}\text { Virus memilikik as am nukleat yang } \\
\text { dibunghus selubung protein }\end{array}$ & 11. & $\begin{array}{l}\text { Ukuran virus terbesar beberapa nanometer } \\
\text { (nyaris tidak tampak dibawah mikroskop } \\
\text { cahaya) }\end{array}$ \\
\hline 2. & & $\begin{array}{l}\text { Virus tidak memilik enzimuntok } \\
\text { melakukanmetab olismes endiii }\end{array}$ & 12. & $\begin{array}{l}\text { Virus tidak memiliki ribosom untuk } \\
\text { mensintesis protein }\end{array}$ \\
\hline 3. & & $\begin{array}{l}\text { Virus memiliki kemampuan replikasi } \\
\text { didalam sel inang }\end{array}$ & 13. & $\begin{array}{l}\text { Virus tidak mampu memperbanyak dirinya } \\
\text { sendiri }\end{array}$ \\
\hline 4. & & $\begin{array}{l}\text { Virus hanya mengandung satt tipe as am } \\
\text { nvikleat (RNA.DNA), tidak pernah } \\
\text { keduanya }\end{array}$ & 14. & $\begin{array}{l}\text { Partikel virus diluar sel inang tidak mempunyai } \\
\text { kegiatan metab olik yang mandiri }\end{array}$ \\
\hline 5. & & $\begin{array}{l}\text { Virus tidak memiliki sel (bersifat } \\
\text { aseluler) }\end{array}$ & 15. & Virus dapat menyebabkan penyakit bagi inang \\
\hline 6. & & Virus tidak memiliki nukleus & 16. & $\begin{array}{l}\text { Beberapajenis virus dilindungi oleh amplop } \\
\text { bermembran }\end{array}$ \\
\hline 7. & & $\begin{array}{l}\text { Virus terdiri atas partikel yang dapat } \\
\text { dikristalkan }\end{array}$ & 17. & $\begin{array}{l}\text { Virus terkecil hanya memalike empat gen dalam } \\
\text { genomnya }\end{array}$ \\
\hline 8. & & $\begin{array}{l}\text { Keberad aan virus s angat bergantung } \\
\text { pada inang y yang ditumpangi }\end{array}$ & 18. & Virus tidak mampu menghasilikan ATP \\
\hline 9. & & $\begin{array}{l}\text { Virus tidak memilik dinding } \\
\text { peptidoglikan }\end{array}$ & 19. & $\begin{array}{l}\text { Virus tidak dapat dibiakkan pada medivm } \\
\text { nutrient dalam tabung reaksi atau cawan petri }\end{array}$ \\
\hline 10. & & $\begin{array}{l}\text { Setiap tipe virus dapat menginfelsis sel } \\
\text { dari ragam inang yang terbatas (host } \\
\text { tange) }\end{array}$ & 20. & $\begin{array}{l}\text { Virus dapat diladasifikasikanberdasarkan jents } \\
\text { asam nukleat yang dimiliki, vikuran dan } \\
\text { morfologinya. }\end{array}$ \\
\hline
\end{tabular}

Gambar I. Soal Kolom Bukti Fakta (KBF) tentang ciri-ciri virus sebagai peralihan benda mati dan makhluk hidup
Tipe soal KBF yang dikembangkan dalam penelitian ini, yaitu siswa diberikan kasus dengan pernyataan ciri-ciri virus sesuai subkonsep, kemudian siswa menentukan jawaban yang benar serta menyimpulkan konsep yang sesuai dengan jawaban yang dipilih. Tipe soal SCG dalam penelitian ini, yaitu siswa diberikan pernyataan tentang tahapantahapan konsep reproduksi virus, konsep yang diberikan terdiri dari konsep benar dan konsep salah, kemudian siswa menentukan konsep yang benar dan mengurutkan tahapan reproduksi virus dengan tepat. Contoh soal KBF pada materi virus, yang telah disusun dan diuji kepada siswa kelas X, XI, dan XII disajikan pada Gambar 1.

Data yang dianalisis dalam penelitian ini didasarkan pada lembar jawaban siswa berkaitan dengan instrumen Assessment Diagnostic pada materi virus. Instrumen dibuat oleh peneliti dan diujikan kepada siswa SMA di enam sekolah berstatus negeri dan swasta yang ada di Kota Magelang pada tahun pelajaran 2017/2018. Instrumen disajikan dalam bentuk soal KBF dan soal essay yang berjumlah lima kasus (terdiri dari 63 kolom pernyataan) serta soal SCG yang berjumlah satu kasus (terdiri dari 20 kolom pernyataan). Sedangkan soal essay berjumlah 5 buah (Gambar 2).

Hasil analisis data selanjutnya digunakan sebagai dasar pertimbangan tentang diterima atau tidaknya setiap butir soal. Jika hasil analisis memenuhi kriteria (valid, reliabel, proporsi tingkat kesukaran seimbang, daya pembeda baik), maka butir soal dapat diterima. Tetapi jika tidak memenuhi kriteria, maka butir soal tidak dapat diterima atau dapat diterima dengan melakukan perbaikan.

\begin{tabular}{|c|c|c|}
\hline \multicolumn{3}{|c|}{ Kasus Replikasi Virus } \\
\hline a) Perhatikan masing-masing ur & zian pada setiap kotak! & \\
\hline $\begin{array}{l}\text { Enzim-enzim } 1 . \\
\text { mentranskripsikan genom virvs } \\
\text { menjadi mRNA virus }\end{array}$ & \begin{tabular}{|l|}
\multicolumn{2}{|c|}{2.} \\
Terjadi hidrolisis DNA pada sel \\
inang
\end{tabular} & $\begin{array}{l}\text { mRNA virus digunakan oleh } \\
\text { mRNA } \\
\text { ribosominang untuk membuat lebih } \\
\text { banyak protein kapsid }\end{array}$ \\
\hline $\begin{array}{l}4 . \\
\text { Terjadi replikasi genom fag tanpa } \\
\text { menghancurkan inang }\end{array}$ & \begin{tabular}{|l|}
5 \\
Virus menempel dan memasuki \\
sel inang (Adsorpsi)
\end{tabular} & $\begin{array}{l}\quad 6 . \\
\text { Pembentukangenom fag didalam } \\
\text { kapsid }\end{array}$ \\
\hline $\begin{array}{l}\text { V. } \\
\text { Virus mencopot selubung, } \\
\text { melepaskan DNA dan protein } \\
\text { kapsid (penetrasi) }\end{array}$ & \begin{tabular}{|c|} 
8. \\
Genom virus dan protein kapsid \\
merakit diri menjadi partikel \\
virus baru yang keluar dari sel
\end{tabular} & $\begin{array}{l}9 . \\
\text { Sel inang mengalami kerusakan } \\
\text { akibat terjadinya osmosis oleh } \\
\text { material genetik virus }\end{array}$ \\
\hline $\begin{array}{l}10 \text {. } \\
\text { DNA bakteri berintegrasi dengan } \\
\text { kromosom vivus menjadi profag }\end{array}$ & $\begin{array}{l}\text { 11. } \\
\begin{array}{l}\text { Pada siklus reproduksi fag, terjadi } \\
\text { kematian sel inang }\end{array}\end{array}$ & $\begin{array}{l}12 . \\
\text { Enzim-enzim inang mereplikasi } \\
\text { genom virus (sintesis) }\end{array}$ \\
\hline
\end{tabular}

Diatas merupakan reaksi siklus reproduksi vinus yang terja di saat vinus m enginfeksi inang Salah satu inangyang dapat terinfeksi oleh yirus a dalah bakteri. Virus yangm enyerang bakted disebut sebagai bakteriofage ataufag, Gunakan angka dari kotak diatas untuk $m$ enjawab pertanyaan berikut ini

b)

Q1: Kotak manakah yang berisi tahapan sildus reproduksi virus dalam proses menginfeksi sel inang? 1) Pilihlah kotak yang sesu

Tulislah pilihan jaw aban anda dalam urutan yang logis......

Q2: Kotakmanakahyang berisi tahapan sildus reproduksi virus fag dalam proses menginfeksi hingga terjadi sildus lisis pada inang?

Pilihlah kotak yang sesuai............

Q3: Kotakmanakah yang berisi tahapan sildus reprodulsi virus fag dalam proses menginfeksi hingga terjadi sildus lisogenik pada inang?
Pilihlah kotak yang sesuai.

Tulislah pithan jaw ab an anda dalam urutan yang logis.........

Gambar 2. Soal Structure Communication Grid(SCG) tentang tahapan replikasi virus dalam menginfeksi inangnya 


\section{Hasil dan pembahasan}

Hasil analisis data pada penelitian ini meliputi: validitas, reliabilitas, tingkat kesukaran dan daya pembeda.

\section{Validitas}

Validitas adalah ketepatan suatu tes dalam mengukur apa yang akan diukur (Purwanto, 2011). Soal memiliki validitas tinggi, jika dapat mengukur kompetensi yang diharapkan. Sebaliknya, soal yang memiliki validitas rendah, apabila tidak bisa mengukur kompetensi yang diharapkan. Butir soal dengan validitas tinggi menunjukkan soal itu secara tepat mampu mengukur kemampuan siswa.
Sebaliknya, butir soal yang bervaliditas rendah mencerminkan perlu diadakannya perbaikan.

Berdasarkan analisis validitas instrumen Assessment Diagnostic materi virus, diketahui bahwa validitas soal SCG sebesar 95\%. SCG merupakan soal yang disusun oleh peneliti pada subbab reproduksi (replikasi) virus. Sedangkan pada soal $\mathrm{KBF}$, validitas tertinggi terdapat pada subbab ciri-ciri virus sebagai benda mati dan makhluk hidup yaitu sebesar $80 \%$. Validitas terendah pada soal KBF terdapat pada subbab peranan virus dalam kehidupan manusia yaitu sebesar 37,5\%. Semua soal essay dinyatakan valid dengan rata-rata persentase $100 \%$. Validitas butir soal pada materi virus dapat diamati pada Tabel 1.

Tabel I. Analisis validitas instrumen Assessment Diagnostic pada materi virus

\begin{tabular}{|c|c|c|c|c|c|c|}
\hline \multirow{2}{*}{\multicolumn{2}{|c|}{ Soal }} & \multirow[b]{2}{*}{ No. Soal } & \multicolumn{2}{|c|}{ Kategori } & \multirow[b]{2}{*}{ JumlahSoal } & \multirow[b]{2}{*}{ Persentase } \\
\hline & & & Valid & Tidak & & \\
\hline \multirow{10}{*}{$\mathrm{KBF}$} & \multirow{2}{*}{ P1 } & $1,2,4,5,6,7,10,12,13,14,15,16,17,18,19,20$ & $\checkmark$ & - & 16 & $80 \%$ \\
\hline & & $3,8,9,11$ & - & $\checkmark$ & 4 & $20 \%$ \\
\hline & \multirow{2}{*}{ P2 } & $3,5,9,11,12,13,15$ & $\checkmark$ & - & 7 & $46.7 \%$ \\
\hline & & $1,2,4,6,7,8,10,14$ & - & $\checkmark$ & 8 & $53.3 \%$ \\
\hline & \multirow{2}{*}{ P4 } & $1,2,6,7,9,10$ & $\checkmark$ & - & 6 & $60 \%$ \\
\hline & & $3,4,5,8$ & - & $\checkmark$ & 4 & $40 \%$ \\
\hline & \multirow{2}{*}{ P5 } & $1,5,6,7,9,10$ & $\checkmark$ & - & 6 & $60 \%$ \\
\hline & & $2,3,4,8$ & - & $\checkmark$ & 4 & $40 \%$ \\
\hline & \multirow{2}{*}{ P6 } & $4,5,6$ & $\checkmark$ & - & 3 & $37.5 \%$ \\
\hline & & $1,2,3,7,8$ & - & $\checkmark$ & 5 & $62.5 \%$ \\
\hline \multirow{2}{*}{ SCG } & \multirow{2}{*}{ P3 } & $\begin{array}{c}1,2,3,4,5,6,7,8,9,10,11,12,14,15,16,17,18, \\
19,20\end{array}$ & $\checkmark$ & - & 19 & $95 \%$ \\
\hline & & 13 & - & $\checkmark$ & 1 & $5 \%$ \\
\hline \multirow{5}{*}{\multicolumn{2}{|c|}{ Essay }} & 1P1 (point a) & $\checkmark$ & - & 1 & $100 \%$ \\
\hline & & $1 \mathrm{P} 2$ (point $\mathrm{b}$ ) & $\checkmark$ & - & 1 & $100 \%$ \\
\hline & & 2 & $\checkmark$ & - & 1 & $100 \%$ \\
\hline & & 5 & $\checkmark$ & - & 1 & $100 \%$ \\
\hline & & 6 & $\checkmark$ & - & 1 & $100 \%$ \\
\hline
\end{tabular}

Keterangan: P1: Pertanyaan nomor 1 (Kasus 1), P2: Pertanyaan nomor 2 (Kasus 2), P3: Pertanyaan nomor 3 (Kasus 3), P4: Pertanyaan nomor 4 (Kasus 4 ), P5: Pertanyaan nomor 5 (Kasus 5), P6: Pertanyaan nomor 6 (Kasus 6)

Tabel 1 menunjukkan hasil analisis validitas butir soal. Diketahui bahwa dari rerata persentase seluruh soal berbentuk KBF (P1, P2, P4, P5, dan P6) dan SCG (P3) terdapat $63,2 \%$ soal valid dan $36,8 \%$ soal tidak valid. Untuk semua soal essay dinyatakan $100 \%$ valid.

Contoh pernyataan soal yang valid pada subbab ciri-ciri virus dapat dilihat pada Gambar 3 .

\begin{tabular}{|c|l|l|}
\hline 1. & & $\begin{array}{l}\text { Virus memiliki asam nukleat yang } \\
\text { dibungkus selubung protein }\end{array}$ \\
\hline 2. & & $\begin{array}{l}\text { Virus tidak memiliki enzim untuk } \\
\text { melakukan metabolisme sendiri }\end{array}$ \\
\hline
\end{tabular}

Gambar 3. Pernyataan soal valid

Sedangkan contoh pernyataan soal yang tidak valid dapat dilihat pada Gambar 4.

\begin{tabular}{|c|l|l|}
\hline 3. & $\begin{array}{l}\text { Virus memiliki kemampuan replikasi } \\
\text { didalam sel inang }\end{array}$ \\
\hline 8. & $\begin{array}{l}\text { Keberadaan virus sangat bergantung } \\
\text { pada inang yang ditumpangi }\end{array}$ \\
\hline
\end{tabular}

Gambar 4. Pernyataan soal tidak valid

Uji validitas diawali dengan melakukan perhitungan terhadap korelasi product moment. Selanjutnya hasil dari perhitungan digunakan sebagai dasar untuk uji reliabilitas, dimana item soal yang tidak valid harus dihilangkan dan direvisi terlebih dulu. Validitas soal berkaitan dengan hasil reliabilitas. Semakin tinggi indeks reliabilitas (keajegan / ketepatan) suatu tes, berarti tinggi pula tingkat validitasnya (Donald, Lucy, \& Asghar, 1982). Sejalan dengan hal tersebut, Amalia \& Widayati (2012) menyatakan bahwa "Reliabilitas sebagai penyokong terbentuknya validitas butir soal”. 
Persentase validitas instrumen Assessment Diagnostic dapat dilihat pada Gambar 5.

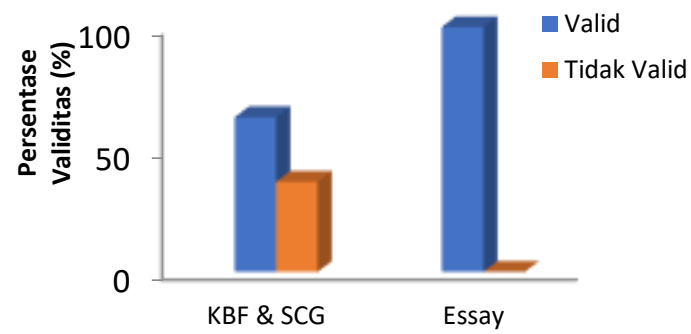

Gambar 5. Validitas Butir Soal KBF, SCG, dan Essay

Dari gambar diatas, dapat dilihat bahwa tingkat validitas instrumen assessmen pada uji coba pertama mendekati $70 \%$ untuk soal KBF dan SCG. Sedangkan soal essay $100 \%$ valid.

Uji validitas berguna sebagai pemetaan butirbutir tes mana yang menyebabkan soal memiliki kriteria jelek, jika validitasnya rendah. Borualogo et al. (2017), berpendapat bahwa "Butir soal dikatakan valid apabila memberikan dukungan besar terhadap skor total". Skor pada butir soal mengakibatkan skor total menjadi tinggi atau rendah. Jika skor pada butir soal memiliki kesejajaran dengan skor total, maka soal dikatakan memiliki validitas tinggi (Nofiana, 2015).

Arifin (2011) mengkategorikan faktor-faktor yang berpengaruh terhadap hasil validitas, yaitu: jawaban siswa, instrumen evaluasi, dan administrasi evaluasi serta penskoran. Dalam pelaksanaannya siswa masih merasa asing dengan bentuk soal yang disediakan dan masih bingung dengan cara mengisi jawaban pada lembar jawab, meskipun pada lembar soal telah disediakan petunjuk cara pengisian jawaban. Siswa juga belum terbiasa untuk memahami maksud dari setiap pertanyaan dan cenderung menjawab sebatas dia memahami pertanyaan yang diberikan dan jarang bertanya. Siswa juga kesulitan untuk menyelesaikan semua soal dalam waktu 90 menit. Faktor jawaban siswa, diantaranya: kecenderungan siswa dalam menjawab soal secara cepat, dan penggunaan gaya bahasa tertentu dalam menjawab soal menjadi penentu valid atau tidaknya suatu butir soal.

\section{Reliabilitas}

Reliabilitas diartikan sebagai konsistensi dari suatu instrumen. Suatu tes dikatakan reliabel jika tetap menunjukkan hasil yang sama apabila diujikan pada kelompok yang sama dalam kesempatan berbeda (Maenani \& Oktova, 2015). Hasil analisis reliabilitas instrumen Assessment Diagnostic pada materi virus disajikan pada Tabel 2.
Tabel 2. Analisis reliabilitas instrumen Assessment Diagnostic pada materi virus

\begin{tabular}{cccc}
\hline Soal & $\begin{array}{c}\text { Nilai } \\
\text { (Cronbach's } \\
\text { Alpha) }\end{array}$ & $\begin{array}{c}\text { N of } \\
\text { items }\end{array}$ & Keterangan \\
\hline KBF \& SCG & 0.759 & 57 & Reliabel \\
Essay & 0.618 & 5 & Reliabel \\
\hline
\end{tabular}

Berdasarkan Tabel 2, Analisis reliabilitas instrumen Assessment Diagnostic pada materi virus menunjukan bahwa semua soal yang diujikan reliabel. Reliabilitas instrumen dibuktikan dengan nilai Cronbach's Alpha (Koefisien Alpha). Cronbach's Alpha merupakan suatu teknik yang digunakan untuk menguji stabilitas internal dari suatu tes, yang penerapannya bukan hanya digunakan pada tes dengan dua pilihan saja, tetapi meliputi reliabilitas skala pengukuran sikap dengan tiga, lima, atau tujuh pilihan (Arifin, 2011).

Cronbach's Alpha merupakan pengukuran keandalan indikator yang digunakan dalam kuesioner penelitian. Alasan penggunaan uji Cronbach's Alpha, yaitu: 1) Teknik ini paling sering digunakan pada pengujian keandalan kuesioner, 2) Mampu mendeteksi indikator-indikator yang tidak konsisten. Nilai Cronbach's Alpha tertera pada Tabel 3.

Tabel 3. Kriteria nilai Cronbach's Alpha

\begin{tabular}{cc}
\hline Nilai Cronbach's Alpha & Kriteria Reliabilitas \\
\hline $0.0-0.2$ & Sangat Rendah \\
$>0.2-0.4$ & Rendah \\
$>0.4-0.6$ & Cukup Tinggi \\
$>0.6-0.8$ & Tinggi \\
$>0.8-1.0$ & Sangat Tinggi \\
\hline
\end{tabular}

Hasil analisis reliabilitas yang baik pada penelitian ini, berkaitan erat dengan hasil validitas instrumen yang telah terukur cukup baik. Hal ini sejalan dengan pernyataan Purwanto (2011), bahwa "Tinggi rendahnya validitas menunjukkan tinggi rendahnya reliabilitas. Soal yang terdiri dari banyak butir soal akan lebih valid daripada yang memiliki sedikit butir, secara otomatis soal yang terdiri dari banyak butir akan lebih reliabel”.

\section{Tingkat Kesukaran}

Tingkat kesukaran adalah pengukuran seberapa besar derajat kesukaran suatu soal (Arifin, 2011). Perhitungan tingkat kesukaran soal menggunakan formula:

Keterangan:

$$
T K=\frac{W L+W H}{n L+n H} x 100 \%
$$

$\mathrm{WL}=$ Jumlah siswa yang menjawab salah dari kelompok bawah

$\mathrm{WH}=$ Jumlah siswa yang menjawab salah dari kelompok atas

$\mathrm{nL}=$ Jumlah kelompok bawah

$\mathrm{nH}=$ Jumlah kelompok atas

Berdasarkan analisis tingkat kesukaran butir soal berbentuk KBF dan SCG, diketahui bahwa 
sebanyak 38,6\% soal termasuk pada kategori mudah, $37,1 \%$ pada kategori sedang, dan $24,3 \%$ soal pada kategori sukar. Sedangkan soal essay terdiri atas
$20 \%$ soal mudah dan $80 \%$ soal sedang. Hasil analisis tingkat kesukaran disajikan pada Tabel 4.

Tabel 4. Analisis tingkat kesukaran instrumen Assessment Diagnostic pada materi virus

\begin{tabular}{|c|c|c|c|c|c|c|c|}
\hline \multirow{2}{*}{$\begin{array}{c}\text { Kategori } \\
\text { Tingkat } \\
\text { Kesukaran }\end{array}$} & \multicolumn{4}{|c|}{ Soal KBF \& SCG } & \multicolumn{3}{|c|}{ Soal Essay } \\
\hline & & No. Soal & Jumlah Soal & Persentase & No. Soal & Jumlah Soal & Persentase \\
\hline \multirow{6}{*}{$\begin{array}{l}\text { Mudah } \\
\mathrm{P}<0,3\end{array}$} & P1 & $\begin{array}{l}1,2,3,5,6,8,10,11 \\
12,13,15,16,18,20\end{array}$ & 14 & $70 \%$ & \multirow{6}{*}{6} & \multirow{6}{*}{1} & \multirow{6}{*}{$20 \%$} \\
\hline & $\mathrm{P} 2$ & $2,7,8,13$ & 4 & $26.67 \%$ & & & \\
\hline & P3 & 1 & 1 & $5 \%$ & & & \\
\hline & P4 & $3,4,5,8$ & 4 & $40 \%$ & & & \\
\hline & P5 & $1,3,7,9$ & 4 & $40 \%$ & & & \\
\hline & P6 & $1,4,6,8$ & 4 & $50 \%$ & & & \\
\hline \multirow{6}{*}{$\begin{array}{c}\text { Sedang } \\
0,3<\mathrm{P}<0,7\end{array}$} & P1 & $4,7,14,17,19$ & 5 & $25 \%$ & \multirow{6}{*}{$\begin{array}{c}1 \mathrm{P} 1, \\
1 \mathrm{P} 2,2, \\
5\end{array}$} & \multirow{6}{*}{4} & \multirow{6}{*}{$80 \%$} \\
\hline & P2 & $\begin{array}{c}3,4,5,6,9,10,11,14 \\
15\end{array}$ & 9 & $60 \%$ & & & \\
\hline & P3 & $2,4,7,8,14,15$ & 6 & $30 \%$ & & & \\
\hline & P4 & 7,10 & 2 & $20 \%$ & & & \\
\hline & P5 & $2,5,6,8,10$ & 5 & $50 \%$ & & & \\
\hline & P6 & $3,5,7$ & 3 & $37.5 \%$ & & & \\
\hline \multirow{7}{*}{$\begin{array}{l}\text { Sukar } \\
\mathrm{P}>0,7\end{array}$} & P1 & 9 & 1 & $5 \%$ & \multirow{7}{*}{ - } & \multirow{7}{*}{-} & \multirow{7}{*}{-} \\
\hline & $\mathrm{P} 2$ & 1,12 & 2 & $13.33 \%$ & & & \\
\hline & P3 & $3,5,6,9,10,11,12$, & 13 & $65 \%$ & & & \\
\hline & & $13,16,17,18,19,20$ & & & & & \\
\hline & P4 & $1,2,6,9$ & 4 & $40 \%$ & & & \\
\hline & P5 & 4 & 1 & $10 \%$ & & & \\
\hline & P6 & 2 & & $12.5 \%$ & & & \\
\hline
\end{tabular}

Berdasarkan Tabel 4, analisis tingkat kesukaran butir soal KBF dan SCG sebanyak 38,6\% soal termasuk pada kategori mudah, 37,1\% soal pada kategori sedang, dan 24,3\% soal pada kategori sukar. Sedangkan soal essay terdiri atas $20 \%$ soal pada kategori mudah dan $80 \%$ soal pada kategori sedang. Pada soal essay, persentase tingkat kesukaran soal didominasi pada kriteria sedang yaitu $80 \%$. Hal ini menunjukkan bahwa sebagian besar soal berbentuk essay, dapat dijawab oleh siswa. Namun soal essay belum memenuhi keseimbangan proporsi tingkat kesukaran.

Tingkat kesukaran soal dapat dikelompokkan ke dalam 3 kategori, yaitu 1) Soal dengan kategori sukar memiliki nilai $\mathrm{P}<0,3,2)$ Soal sedang memiliki nilai $\mathrm{P}=0,3-0,7$, dan 3 ) Soal mudah memiliki nilai $\mathrm{P}>0,7$. Persentase tingkat kesukaran soal dapat diamati pada Gambar 6.

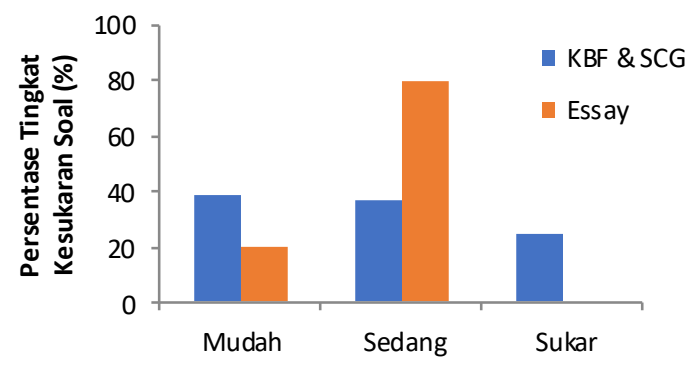

Gambar 6. Tingkat Kesukaran Butir Soal KBF, SCG, dan Essay
Berdasarkan Gambar 6, persentase soal pada kategori sedang untuk soal KBF, SCG, dan essay mendominasi pada aspek tingkat kesukaran instrumen. Soal dikatakan baik apabila tidak terlalu sukar dan tidak terlalu mudah. Butir soal yang terlalu mudah atau terlalu sukar boleh digunakan, tetapi dengan memperhatikan proporsinya.

Naskah soal sebaiknya memiliki proporsi tingkat kesukaran berimbang, yaitu: $25 \%$ soal sukar, $50 \%$ soal sedang, dan 25\% soal mudah (Amalia \& Widayati, 2012). Untuk memperoleh hasil belajar yang baik, proporsi tingkat kesukaran soal harus tersebar secara normal. Terdapat tiga perhitungan perbandingan soal sukar, sedang, mudah dalam mencapai proporsi normal, yaitu: 1) 25\%:50\% : $25 \%$, atau 2) $20 \%: 60 \%: 20 \%$, atau 3) $15 \%: 70 \%$ : 15\% (Arifin, 2011).

Menurut Maenani \& Oktova (2015), meminta judgment/penilaian dari guru merupakan salah satu upaya untuk memperoleh komposisi soal dengan kriteria yang sesuai. Akan tetapi hal ini juga memiliki kelemahan, sebab belum tentu butir soal yang dianggap guru sebagai soal yang sulit juga dirasakan sulit oleh siswa. Guru mengklasifikasikan butir soal pada kriteria tingkat kesukaran tertentu (mudah, sedang, dan sukar) berdasarkan intuisinya. Sehingga sangat sulit menentukan kriteria suatu butir soal, sebelum siswa melakukan tes.

Beberapa hal yang harus diperhatikan dalam penyusunan soal berkaitan dengan tingkat kesukaran, 
yaitu: 1) Soal yang terlalu sukar atau mudah tidak memberikan informasi yang berguna bagi sebagian besar siswa karena syarat distribusi jawaban tidak terpenuhi, 2) Soal masih memenuhi syarat untuk diterima jika menunjukkan jawaban yang merata, logis, dan daya bedanya negatif (kecuali kunci jawaban), 3) Jika daya pembeda memenuhi kriteria, maka soal yang terlalu mudah atau sukar tersebut dapat diterima, 4) Jika daya pembeda belum memenuhi kriteria, maka soal tersebut harus direvisi dan diuji coba lagi (Arifin, 2011).

\section{Daya Pembeda}

Daya pembeda adalah kemampuan soal untuk membedakan siswa pandai dan siswa yang kurang pandai). Analisis daya pembeda menggunakan formula:

$$
D P=\frac{(W L-W H)}{n}
$$

Keterangan:

$\mathrm{DP}=$ Daya pembeda

$\mathrm{WL}=$ Jumlah siswa yang gagal dari kelompok bawah

$\mathrm{WH}=$ Jumlah siswa yang gagal dari kelompok atas

$\mathrm{n} \quad=27 \% \mathrm{x}$ jumlah responden

Berdasarkan hasil analisis daya pembeda soal, persentase instrumen Assessment Diagnosticpada materi virus terdiri atas $62,2 \%$ soal dengan kategori jelek, 31,5\% soal dengan kategori cukup, dan 6,3\% soal dengan kategori baik pada soal berbentuk $\mathrm{KBF}$ dan SCG. Sedangkan pada soal essay terdiri atas $60 \%$ soal dengan kategori daya pembeda cukup dan $40 \%$ soal dengan kategori daya pembeda baik. Analisis daya pembeda butir soal Assessment Diagnostic pada materi virus dapat dilihat pada Tabel 5.

Tabel 5. Analisis daya pembeda instrumen Assessment Diagnostic pada materi virus

\begin{tabular}{|c|c|c|c|c|c|c|c|}
\hline \multirow{2}{*}{$\begin{array}{c}\text { KategoriDaya } \\
\text { Beda }\end{array}$} & \multicolumn{4}{|c|}{ Soal KBF \& SCG } & \multicolumn{3}{|c|}{ Soal Essay } \\
\hline & & No. Soal & Jumlah Soal & Persentase & No. Soal & Jumlah Soal & Persentase \\
\hline \multirow{6}{*}{$\begin{array}{l}\text { Jelek } \\
<0.20\end{array}$} & P1 & $1,3,8,9,10,11,13,15,20$ & 9 & $45 \%$ & \multirow{6}{*}{-} & \multirow[t]{6}{*}{ r } & \multirow{6}{*}{ 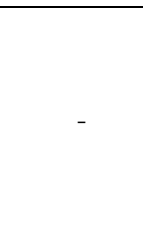 } \\
\hline & $\mathrm{P} 2$ & $1-14$ & 14 & $93.3 \%$ & & & \\
\hline & P3 & $6,9,13,16,18,20$ & 6 & $30 \%$ & & & \\
\hline & P4 & $1,3,4,5,8,9$ & 6 & $60 \%$ & & & \\
\hline & P5 & $1,2,3,4,5,7,8$ & 7 & $70 \%$ & & & \\
\hline & P6 & $1,2,3,6,7,8$ & 6 & $75 \%$ & & & \\
\hline \multirow{6}{*}{$\begin{array}{l}\text { Cukup } \\
0.2-0.4\end{array}$} & P1 & $\begin{array}{c}2,4,5,6,7,12,14,16,17 \\
18,19\end{array}$ & 11 & $55 \%$ & \multirow{6}{*}{$\begin{array}{c}\text { 1P1, } \\
\text { 1P2 } \\
5\end{array}$} & \multirow{6}{*}{3} & \multirow{6}{*}{$60 \%$} \\
\hline & $\mathrm{P} 2$ & 15 & 1 & $6.67 \%$ & & & \\
\hline & P3 & $1,2,3,4,5,11,12,17,19$ & 9 & $45 \%$ & & & \\
\hline & P4 & $2,6,7,10$ & 4 & $40 \%$ & & & \\
\hline & P5 & $6,9,10$ & 3 & $30 \%$ & & & \\
\hline & P6 & 4 & 1 & $12.5 \%$ & & & \\
\hline Baik & P3 & $7,8,10,14,15$ & 5 & $25 \%$ & \multirow{2}{*}{2,6} & \multirow{2}{*}{2} & \multirow{2}{*}{$40 \%$} \\
\hline$>0.40$ & P6 & 5 & 1 & $12.5 \%$ & & & \\
\hline
\end{tabular}

Tabel 5 menunjukkan $62,2 \%$ soal termasuk dalam kategori jelek; $31,5 \%$ soal dengan kategori cukup, dan $6,3 \%$ soal dengan kategori baik pada KBF dan SCG. Sedangkan pada soal essay, 60\% soal memiliki daya pembeda cukup dan $40 \%$ soal memiliki daya pembeda baik. Persentase daya pembeda instrumen Assessment Diagnostic dapat dilihat pada Gambar 7.

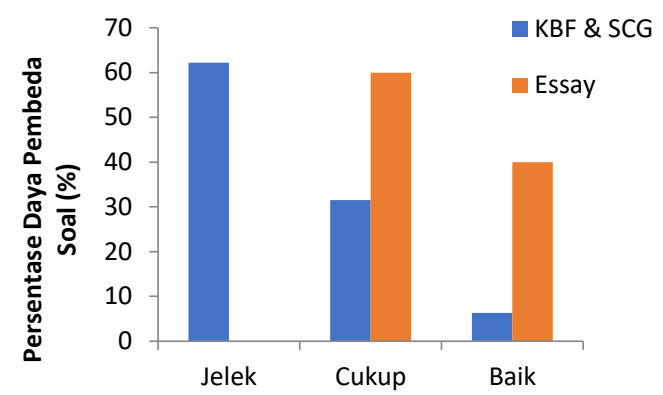

Gambar 7. Persentase daya pembeda butir soal KBF, SCG, dan Essay
Assessment Diagnostic pada aspek daya pembeda memiliki kriteria yang tidak baik. Persentase soal yang jelek lebih besar dari 50\% yang berarti sebagian besar soal tidak mempunyai daya pembeda.

Soal mempunyai daya pembeda, jika soal dapat dijawab oleh siswa berkemampuan tinggi tetapi tidak dapat dijawab oleh siswa berkemampuan rendah. Jika soal dapat dijawab oleh semua siswa, baik siswa pintar maupun kurang pintar, maka soal tersebut tidak mempunyai daya beda. Begitu juga jika siswa pintar dan siswa kurang pintar tidak bisa menjawab, berarti soal tersebut tidak baik karena tidak mempunyai daya pembeda.

Butir soal dengan kriteria jelek sebaiknya tidak digunakan, butir soal yang memiliki daya beda cukup dapat diterima dengan perbaikan, dan butir soal yang memiliki daya beda baik dapat diterima tanpa perbaikan.

Untuk meningkatkan daya pembeda, sebaiknya dilakukan ujicoba soal sebelum digunakan. Beberapa 
faktor penunjang, agar diperoleh soal dengan daya pembeda baik menurut pendapat Maenani \& Oktova (2015), yaitu: mengoptimalkan proses penyusunan dan perakitan soal sesuai dengan kaidah, rumusan soal harus jelas sehingga tidak menimbulkan penafsiran ganda, gambar, grafik, tabel, dan diagram harus jelas dan berfungsi, soal menggunakan bahasa yang komunikatif.

Berdasarkan hasil analisis butir soal yang telah dilakukan, peneliti menentukan kategorisasi dalam menentukan butir soal mana yang diterima, diterima dengan perbaikan, dan butir soal yang ditolak. Matriks kategorisasi analisis kualitas soal dapat dilihat pada Tabel 6.

Tabel 6. Kategorisasi kualitas butir soal instrumen Assessment Diagnostic pada materi virus

\begin{tabular}{|c|c|c|c|c|c|c|}
\hline \multirow{2}{*}{ Validitas } & \multirow{2}{*}{ Reliabilitas } & \multicolumn{3}{|c|}{$\begin{array}{c}\text { Aspek } \\
\text { Tingkat Kesukaran }\end{array}$} & \multirow{2}{*}{ Daya Pembeda } & \multirow[t]{2}{*}{ Kesimpulan Kategorisasi } \\
\hline & & Mudah & Sedang & Sukar & & \\
\hline \multirow{9}{*}{ Valid } & & $\checkmark$ & & & & Diterima \\
\hline & $\checkmark$ & & $\checkmark$ & & Baik & Diterima \\
\hline & & & & $\checkmark$ & & Diterima \\
\hline & & $\checkmark$ & & & & Diterima \\
\hline & $\checkmark$ & & $\checkmark$ & & Cukup & Diterima \\
\hline & & & & $\checkmark$ & & Diterima \\
\hline & & $\checkmark$ & & & & Diterima dengan perbaikan \\
\hline & $\checkmark$ & & $\checkmark$ & & Jelek & Diterima dengan perbaikan \\
\hline & & & & $\checkmark$ & & Diterima dengan perbaikan \\
\hline \multirow{9}{*}{ Tidak Valid } & & $\checkmark$ & & & & Ditolak \\
\hline & $\checkmark$ & & $\checkmark$ & & Baik & Ditolak \\
\hline & & & & $\checkmark$ & & Ditolak \\
\hline & & $\checkmark$ & & & & Ditolak \\
\hline & $\checkmark$ & & $\checkmark$ & & Cukup & Ditolak \\
\hline & & & & $\checkmark$ & & Ditolak \\
\hline & & $\checkmark$ & & & & Ditolak \\
\hline & $\checkmark$ & & $\checkmark$ & & Jelek & Ditolak \\
\hline & & & & $\checkmark$ & & Ditolak \\
\hline
\end{tabular}

Berdasarkan hasil analisis kuantitatif butir soal, diperoleh kesimpulan kategorisasi dimana 40 soal diterima, 23 soal yang memiliki daya pembeda jelek akan diperbaiki, dan 25 butir soal tidak valid dengan daya pembeda jelek akan dibuang. Setelah dilakukan revisi, selanjutnya instrumen akan diuji kembali pada uji coba kedua.

Menurut Amalia \& Widayati (2012), soal yang berkualitas adalah soal yang dapat memberikan informasi yang tepat dalam menentukan siswa yang sudah dan belum menguasai materi yang diajarkan. Manfaat melakukan analisis butir soal, yaitu: 1) Memperoleh informasi perbaikan soal dengan mengidentifikasi soal-soal yang kurang baik, 2) Meningkatkan validitas dan reliabilitas soal, dan 3) Meningkatkan keterampilan guru dalam menyusun instrumen.

Hasil analisis kualitas butir soal diukur berdasarkan jawaban siswa. Kemampuan siswa dalam menjawab soal Assessment Diagnostic dipengaruhi oleh banyak faktor. Beberapa penyebab kesulitan siswa menurut peneliti diantaranya: 1) Siswa tidak pernah dihadapkan pada bentuk soal KBF dan SCG sehingga merasa asing dengan bentuk soal tersebut, 2) Pemahaman siswa terkait materi virus hanya sebatas pada tahapan mengingat/hafalan, 3) Motivasi, minat, dan perhatian siswa yang rendah pada pelajaran biologi khususnya materi virus akan menimbulkan ketidaktekunan belajar yang akhirnya berdampak pada menurunnya prestasi belajar siswa (Winarni, 2014).

\section{Simpulan}

Validitas soal KBF dan SCG sebesar 63,2\% dan soal essay $100 \%$ valid, semua butir soal reliabel, persentase tingkat kesukaran soal KBF dan SCG yaitu 38,6\% mudah, 37,1\% sedang, dan 24,3\% sukar. Pada soal essay $20 \%$ soal pada kategori mudah dan $80 \%$ soal pada kategori sedang; Persentase daya pembeda soal KBF dan SCG yaitu 62,2\% jelek, 31,5\% cukup dan 6,3\% baik. Pada soal essay, 60\% soal dengan kategori daya pembeda cukup dan $40 \%$ soal dengan kategori baik. Berdasarkan hasil analisis kuantitatif butir soal, 40 soal diterima, 23 soal yang memiliki daya pembeda jelek akan diperbaiki, dan 25 butir soal tidak valid dengan daya pembeda jelek akan dibuang.

\section{Referensi}

Amalia, A. N., \& Widayati, A. (2012). Analisis butir soal tes kendali mutu kelas XII SMA mata pelajaran ekonomi akuntansi di kota yogyakarta tahun 2012. Jurnal Pendidikan Akuntansi Indonesia, 10(1), 1-26. https://doi.org/10.21831/ jpai.v10i1.919 
Aprilia, N. (2016). Implementasi model pembelajaran reflektif untuk meningkatkan kemampuan pemahaman mahasiswa pendidikan biologi pada mata kuliah strategi pembelajaran di program studi FKIP Universitas Ahmad Dahlan. JURNAL BIOEDUKATIKA, 4(1), 27-30. https://doi.org/10.26555/bioedukatika.v4i1.4 739

Arifin, Z. (2011). Evaluasi pembelajaran. bandung: PT Remaja Rosdakarya.

Ayu, D., Saputri, F., \& Widyaningrum, T. (2016). Misconceptions analysis on the virus chapter in biology textbooks for high school students grade $\mathrm{X}, 1(1), 31-37$. https://doi.org/ 10.15294/ijal.v1i1.7781

Borualogo, I. S., Kusdiyati, S., Susandari, S., \& Sirodj, D. A. N. (2017). Analisis item soal UTS pedologi semester ganjil 2015-2016. SCHEMA Journal of Psychological Research, 3(1), 46-57. Diambil dari https://ejournal.unisba.ac.id/ index.php/schema/article/view/1808/1761

Chi, M. T. H., Slotta, J. D., \& Leeuw, N. de. (1994). From things to processes: A theory of conceptual change for learning science concepts. Journal Learning and Instruction, 4, 27-43. Diambil dari http://www.public.asu.edu/ $\sim$ mtchi/papers/ChiSlottaLeeuw.pdf

Clark, I. (2015). Formative assessment: Translating highlevel curriculum principles into classroom practice. The Curriculum Journal, 26(1), 91114. https://doi.org/10.1080/09585176. 2014.990911

Donald, A., Lucy, J. C., \& Asghar, A. (1982). Pengantar penelitian dalam pendidikan. (A. Furchan, Penerj.). Surabaya: Usaha Nasional.

Güne, M. H., Güne, O., \& Hoplan, M. (2011). The using of computer for elimination of misconceptions about photosynthesis. Procedia - Social and Behavioral Sciences, 15, 1130-1134. https://doi.org/10.1016/j.sbspro.2011.03.251

Gurel, D. K., Ery1lmaz, A., \& McDermott, L. C. (2015). A review and comparison of diagnostic instruments to identify students' misconceptions in science. Eurasia Journal of Mathematics, Science and Technology Education, 11(5), 989-1008. https://doi.org/10.12973/eurasia. 2015.1369a

Isaac, S., \& Michael, W. B. (1995). Handbook in research and evaluation: A collection of principles, methods, and strategies useful in the planning, design, and evaluation of studies in education and the behavioral sciences ( 3 ed.). San Diego: EdiTS. Google Books

Jayawardana, H. B. A. (2017). Paradigma pembelajaran biologi di era digital. JURNAL BIOEDUKATIKA, 5(1), 12-17. https:// doi.org/10.26555/bioedukatika.v5i1.5628
Johnstone, A. H., Bahar, M., \& Hansell, M. H. (2000). Structural communication grids: A valuable assessment and diagnostic tool for science teachers. Journal of Biological Education, 34(2), 87-89. https://doi.org/10.1080/00219266. 2000.9655691

Kara, F., \& Çelikler, D. (2015). Development of achievement test: Validity and reliability study for achievement test on matter changing. Journal of Education and Practice, 6(24), 21-26. Diambil dari https://iiste.org/Journals/ index.php/JEP/article/view/25254/25854

Kose, E. O., Pekel, O., \& Hasenekoglu, I. (2009). Misconceptions and alternative concepts in biology textbooks: Photosynthesis and respiration. Journal of Science Education, 10(2), 91-93. Diambil dari http://chinakxjy.com/ downloads/2006-2010.html

Maenani, L., \& Oktova, R. (2015). Analisis butir soal fisika ulangan umum kenaikan kelas $\mathrm{X}$ Madrasah Aliyah Se-Kabupaten Banjarnegara, Jawa Tengah tahun pelajaran 2011/2012. Jurnal Berkala Fisika Indonesia, 7(1), 5-11. Diambil dari http://journal.uad.ac.id/ index.php/BFI/article/view/1539/1049

Mustaqim, T. A., Zulfiani, Z., \& Herlanti, Y. (2014). Identifikasi miskonsepsi siswa dengan menggunakan metode certainty of response index (CRI) pada konsep fotosintesis dan respirasi tumbuhan. Edusains, 6(2), 145-152. https://doi.org/10.15408/es.v6i2.1117

Nofiana, M. (2015). Kualitas penulisan butir soal ujian nasional biologi tahun 2014/2015 ditinjau dari aspek teoritik. Saintifika, 17(1), 1-13. Diambil dari https://jurnal.unej.ac.id/index.php/STF/ article/view/3127/2495

Nofiana, M., Sajidan, S., \& Puguh. (2016). Pengembangan instrumen evaluasi higher order thinking skills pada materi kingdom plantae. Pedagogi Hayati, 1(1), 46-53. Diambil dari http:/ /ojs.umrah.ac.id/index.php/pedagogihay ati/article/view/37

Osborne, J. (2004). IDEAS: Ideas, evidence and argument in science (IDEAS) project. London: King's College London.

Purwanto. (2011). Evaluasi hasil belajar. Yogyakarta: Pustaka Pelajar.

Sudarisman, S. (2015). Memahami hakikat dan karakteristik pembelajaran biologi dalam upaya menjawab tantangan abad 21 serta optimalisasi implementasi kurikulum 2013. Florea: Jurnal Biologi dan Pembelajarannya, 2(1), 29-35. https://doi.org/10.25273/florea.v2i1.403

Suparno, P. (2013). Miskonsepsi dan perubahan konsep dalam pendidikan fisika. Jakarta: PT Gramedia Widiasarana Indonesia. Google Books 
Suratno, T. (2008). Konstruktivisme, konsepsi alternatif dan perubahan konseptual dalam pendidikan IPA. Jurnal Pendidikan Dasar, 10(1), 1-3.

Syahrul, D. A., \& Setyarsih, W. (2015). Identifikasi miskonsepsi dan penyebab miskonsepsi siswa dengan three-tier diagnostic test pada materi dinamika rotasi. Jurnal Inovasi Pendidikan Fisika, 4(3), 67-70. Diambil dari http://jurnalmahasiswa.unesa.ac.id/index.php/i novasi-pendidikan-fisika/article/view/13305/ 12214

Winarni, S. (2014). Pengaruh perhatian guru, motivasi belajar, dan kecerdasan emosional terhadap prestasi belajar biologi siswa SMA Negeri 2 Bantul. JURNAL BIOEDUKATIKA, 2(1), 42. https://doi.org/10.26555/bioedukatika.v2i1.4 111

Yankovskaya, A., Levin, I., \& Fuks, I. (2014). Assessment of teaching and learning by mixed diagnostic testing. In Proceedings of the Frontiers in Mathematics and Science Education Research Conference. Famagusta. Diambil dari https://www.researchgate.net/profile/Ilya_Lev in/publication/262915611_Assessment_of_Te aching_and_Learning_by_Mixed_Diagnostic_ Testing/links/58a4923c92851cf0e3894741/ Assessment-of-Teaching-and-Learning-byMixed-Diagnostic-Testing.pdf 